\title{
Forum Shopping in EC Tax Law in the Context of Legal Pluralism: Spontaneous Order as the Optimal Solution or Taxpayers' Rights to a Code of Legality?
}

\author{
Prof. Dr. Ana Paula Dourado, University of Lisbon
}

\section{Legal remedies in EC tax law and legal pluralism}

Legal remedies in European Community (EC) law result not only from EC legal sources, but also from national ones. ${ }^{1}$ In the absence of Community legislation on the enforcement of EC law at the Member States' domestic legal systems, the principle of national procedural autonomy as constructed by the European Court of Justice (ECJ) plays a quite relevant role, although it is in tension with other principles.

The issue of legal remedies in EC law unavoidably faces the problems resulting from legal pluralism: interaction of legislators, judges and other different private and public actors participating in different normative systems and belonging to different legal orders and levels (infra-, inter- and supranational). ${ }^{2}$

This situation raises at least one difficult question: how is it possible to adjudicate legal access to courts according to the minimum requirement of justice if the legal system is not coherent? ${ }^{3}$

To deal with the multiplicity of national nonharmonized legal remedies in the EU, the ECJ puts into play interacting and often conflicting principles, using a standards based approach: the primary role of national procedural law ("national procedural auton- omy') or the 'no new remedies rule', ${ }^{4}$ (as long as) the principles of effectiveness and equivalence (are observed), and the principle of legal certainty.

The first three principles were introduced in the Rewe $^{5}$ and Comet $^{6}$ cases:

In the absence of Community rules on the refund of national charges levied though not due, it is for the domestic legal system of each Member State to designate the courts and tribunals having jurisdiction and to lay down the detailed procedural rules governing actions for safeguarding rights which individuals derive from Community law ${ }^{7} \ldots$ [principle of national procedural autonomy] ..., provided first, that such rules are not less favorable than those governing similar domestic actions 8 (principle of equivalence) and secondly, that they do not render virtually impossible or excessively difficult the exercise of rights conferred by Community law ${ }^{9}$ (principle of effectiveness).

They were often later developed by the ECJ as conflicting principles, especially when the principle of effectiveness has been given priority: effectiveness is then closely linked to emphasizing the substantive EC law right and the 'no new remedies rule' becomes secondary, as results from Dekker, ${ }^{10}$ Factortame $I,{ }^{11}$

\section{Notes}

Legal Remedies in European Tax Law was the subject of an International Conference held in Cetara-Salerno (Italy) 12-13 Jun. 2008, the results of which will be published.

2 On the legal pluralism in EC law and emerging problems to national courts and the ECJ, see Miguel Poiares Maduro, A Constituição Plural, Constitucionalismo e União Europeia (Principia: São João do Estoril-Cascais, 2006), Chs 2 and 3.

3 See, on the difficulties resulting from legal pluralism to legal actors and democracy, Klaus Günther, 'Rechtspluralismus und universaler Code der Legalität: Globalisierung als rechtstheoretiches Problem', Die Öffentlichkeit der Vernunft und die Vernunft der Öffentlichkeit, Festschrift für Jürgen Habermas, Hrsg. von Lutz Wingert und Klaus Günther (Suhrkamp: Frankfurt-am-Main, 2001), 541.

Paul Craig \& Gráinne De Búrca, EU Law, Text, Cases and Materials, 4th edn (Oxford, New York: Oxford University Press, 2008 ), 311 et seq.

ECJ Case 33/76 [1976] ECR 1989.

ECJ Case 45/76[1976] ECR 2043.

Author's emphasis.

Ibid.

Ibid.

10 ECJ Case C-177/88 Dekker v. Stichting voor Jong Volwassenen (VJV) Plus [1990], I-ECR 395, para. 26.

11 ECJ Case C-213/89 R. v. Secretary of State for Transport, ex parte Factortame Ltd and Others [1990] ECR I-2433. 
Cotter $^{12}$ and Emmott, ${ }^{13}$ and Metallgesellschaft and Hoechst. ${ }^{14} 15$ For example, in Metallgesellschaft and Hoechst the very substance of the plaintiff's claim was the interest which would have accrued had the taxpayer not been subject to discriminatory advance taxation (the right results directly from the breach of Article 43 of the EC Treaty), and it was not relevant that restitution might not be available under English law in the concrete circumstances: restitution due to loss of the use of money where no principal sum was due. ${ }^{16}$

In turn, legal certainty in litigation is assured by the acceptance of reasonable time limits for bringing proceedings against administrative decisions (see Arcor and $1-21^{17}$ ), including tax assessments, and mitigated by the possibility of reopening of deadlines for the challenge of administrative acts (including tax assessments) due to a subsequent ECJ decision (see Kühne and Heitz, ${ }^{18}$ paragraph 24).

In the field of tax law, where the legal repercussions of the transnational expansion of the market economy are highly noticeable, potential litigants can take advantage of the indeterminacy of the aforementioned standards approach used by the ECJ. The very fact that more than one legal remedy can be used and that more than one Member State can legitimately exercise jurisdiction over the parties, gives rise to the possibility that the outcome of a case depends on the choice of the forum.

In this context, the transfer pricing Arbitration Convention (90/436/EEC of 23 July 1990) works in the opposite direction - since its application directly results from an adjustment of profits by a certain tax administration, the number of possible fora is dependent on the administration that makes the adjustment and therefore reduced, and in this case the race to the fora takes place between more and less efficient tax authorities.

\section{Promoting forum shopping between national administrative tax appeals and damages claims}

Let us now consider the interplay between national administrative (tax) appeals and damages claims in proceedings that challenge charges levied in breach of EC law. In many Member States, time limits for bringing administrative appeal procedures are much shorter than time-limits for bringing civil restitution of damages proceedings. Whereas in Arcor and $i-21$ (and Deggendorf, ${ }^{19}$ National Farmers' Union $^{20}$ and Assi Domän $\mathrm{Kraft}^{21}$ ), the ECJ clearly reiterated that a decision susceptible to appeal, but unchallenged becomes final, it seems on the contrary to result from the Thin Cap Group Litigation ${ }^{22}$ that EC law provides access to (civil) tort proceedings to interested taxpayers who failed to use all remedies available to them under national law, because they expected to be turned down by the national authorities. ${ }^{23}$

Cases like the Thin Cap Group Litigation and the existing hesitation of the ECJ on the weight to give to the 'no new rules remedy', the principle of effectiveness, and the principle of legal certainty attached to the acceptance of reasonable time limits promote (at least at first sight) forum shopping between the two types of procedures. Whereas in administrative tax appeals time limits are the only relevant condition to claim, liability for damages results from true consequential loss and some conditions must be fulfilled (Francov$i c h,{ }^{24}$ and Brasserie du Pêcheur and Factortame $\left.{ }^{25}\right)$ : the rule of law infringed must be intended to confer rights on individuals; the breach of Community law must be sufficiently serious; and there must be a direct causal link between the breach and the harm suffered. Moreover, the injured person must have shown reasonable diligence in order to avoid the loss or damage or limit its extent, and availed himself in time of all the legal remedies available to him.

In direct tax law cases, on the one hand, the second condition ('sufficiently serious breach of law') may be

\section{Notes}

12 ECJ Case C-377/89 Cotter and MacDermott v. Minister for Social Welfare [1991] ECR I-1155.

13 ECJ Case C-208/90 Emmott v. Minister for Social Welfare [1991] ECR I-4269.

14 ECJ Case C-410/98 Metallgesellschaft and Hoechst v. Inland Revenue [2001] ECR I-4727.

15 Paul Craig \& Gráinne De Búrca, See n. 4 above, 313 et seq.

16 Ibid., 319-320.

17 Joined Cases C-392/04 and C-422/04 [2006] ECR I-8559.

18 ECJ Case C-453/00 Kühne und Heitz NV v Productschap voor pluimvee en eieren [2004] ECR I-837.

19 ECJ Case C-188/92 TWD Textilwerke Deggendorf [1994] ECR I-833.

20 ECJ Case C-241/01 National Farmers' Union v. Secrétariat général du gouvernement [2002] ECR I-9079.

21 ECJ Case C-310/97 P Commission v. AssiDomän Kraft Products AB and Others [1999] ECR I-5363.

22 ECJ Case C-524/04 Test Claimants in the Thin Cap Group Litigation v. Commissioners of Inland Revenue [2007] ECR I-2107.

23 In this sense, Peter J. Wattel, 'National Procedural Autonomy and Effectiveness of EC Law: Challenge the Charge, File for Restitution, Sue for Damages?', Legal Issues of Economic Integration 35, no. 2 (2008): 112.

24 Joined Cases C-6/90 and C-9/90 Francovich and Bonifaci v. Italy [1991] ECR I-5357.

25 ECJ Joined Cases C-46/93 and C-48/93, Brasserie du Pêcheur SA v. Germany, and R. v. Secretary of State for Transport, ex parte Factortame Ltd and Others [1996] ECR I-1029. 
difficult to fulfil, and the litigant taxpayer takes some risk if he avoids the legal remedies with shorter time limits available to him, but on the other hand, the ECJ is very tolerant when interpreting the 'reasonable diligence' showed by the taxpayer.

Thus, one question is whether it is possible to demonstrate in direct tax law issues the "sufficiently serious breach of law', since the clarity and precision of the rule infringed is hard to achieve. ${ }^{26}$

Both in the Thin Cap Group Litigation and in the FII Group Litigation, ${ }^{27}$ the Court links the 'sufficient seriousness of the breach of law' criterion to the existence of settled case law or acte clair/acte éclairé. According to the Court, in the field of direct taxation, clarity of the rules is only progressively achieved (Thin Cap Group Litigation, paragraphs 120-121; cf. FII Group Litigation, paragraphs 213-217). Moreover, in the Thin Cap Group Litigation, although crossreferring to the Lankhorst-Hoborst ${ }^{28}$ ('Until delivery of the judgment in Lankhorst-Hohorst, the problem raised by the current reference for a preliminary ruling had not, as such, been addressed in the Court's caselaw', Thin Cap Group Litigation, paragraph 121), the ECJ is not very assertive on whether (in)compatibility of the thin cap regimes with EC law is clear since the Lankhorst-Hohorst, and therefore on whether since the latter case a Member State with a thin cap regime similar to the one analyzed in Lankhorst-Hohorst 'persists in the breach of EC law', seriously breaching it. However, the same Court has argued that acte clair/ acte éclairé can be achieved in one single judgment, as results from Meilicke, ${ }^{29}$ which cross-refers to Verkooijen. ${ }^{30}$

On the contrary, when interpreting the 'reasonable diligence' showed by the taxpayer in tax issues, the Court has reiterated its argument in Metallgesellschaft (paragraph 106):

the exercise of rights conferred on private persons by directly applicable provisions of Community law would be rendered impossible or excessively difficult if their claims for restitution or compensation based on infringement of Community law were rejected or reduced solely because the persons concerned had not applied for a tax advantage which national law denied them, with a view to challenging the refusal of the tax authorities by means of the legal remedies provided for that purpose, invoking the primacy and direct effect of
Community law. (paragraph 125, Thin Cap Group Litigation)

By broadly interpreting the condition on the reasonable diligence of the taxpayer, the ECJ is promoting forum shopping, as the taxpayer may avoid the barring effect of time limits for administrative appeal. ${ }^{31}$

In general, the fact that the ECJ is still searching for a proportional combination of the aforementioned principles of autonomy of national legal procedures, effectiveness and equivalence and legal certainty, leads to uncertainty about which legal remedy to adopt and may after all reduce forum shopping. In other words, the indeterminacy of the conditions underlying liability for damages, leads in turn to the uncertainty of the results of forum shopping.

Another source of uncertainty resulting from the ECJ case law lies in the difficulty to distinguish whether a claim for interest aims at simply restoring legality - putting the taxpayer back in the situation that he would have been, if the national measure was lawful - or at compensating for consequential loss. According to the Court, the character of the claim for interest in the case of domestic tax law contrary to the EC Treaty that simply implies a too early payment of tax and therefore a cash flow disadvantage, is restitutionary (Metallgesellschaft, paragraphs 87-88). However, converting loan capital into equity in order to comply with thin cap rules, or tax advantages waived by a resident company in order to offset unlawful tax, or expenses incurred by the companies in order to comply with the national legislation at issue can be true consequential losses, and therefore recovery of the amounts can be obtained only through a claim for damages (Thin Cap Group Litigation, paragraph 113 et seq.).

\section{Is forum shopping harmful?}

As illustrated, the possibility of forum shopping is related to a context of uncertainty. ${ }^{32}$

But what is wrong with forum shopping? Is it true that forum shopping prevents from treating like cases alike and from granting access to equal rights and participation? Are the taxpayers' legitimate expectations that the same circumstances should always lead to the same outcome to protect?

\section{Notes}

6 See Ana Paula Dourado \& Ricardo da Palma Borges (eds), The Acte Clair in EC Direct Tax Law (Amsterdam: IBFD, 2008), passim.

27 ECJ Case C-446/04 Test Claimants in the FII Group Litigation v. Commissioners of Inland Revenue [2006] ECR I-11753.

28 ECJ Case C-324/00 Lankhorst-Hohorst v Finanzamt Steinfurt [2002] ECR I-11779.

29 ECJ Case C-292/04 Wienand Meilicke, Heidi Christa Weyde, Marina Stöffler v Finanzamt Bonn-Innenstadt.

30 ECJ Case C-35/98 Staatssecretaris van Financien v Verkooijen.

31 See Peter J. Wattel, n. 23 above, 112.

32 See Nita Ghei \& Francesco Parisi, 'Adverse Selection and Moral Hazard in Forum Shopping: Conflicts Law As Spontaneous Order', George Mason University School of Law, 03-42, Law and Economics WP Series, 13, < http://ssrn.com/abstract_id = >. 
There are good reasons to believe that forum shopping raises problems of adverse selection (which is the situation where parties have asymmetric information ${ }^{33}$ ) and moral hazard (e.g., the taxpayer's incentive to take precaution to litigate within time limits is reduced). ${ }^{34}$ Besides, when forum shopping and procedural innovations result in higher damage awards, they seem to increase settlement costs and the probability of settlement. ${ }^{35}$

An ideal legal pluralism would satisfy the "mirrorimage' test: 'the same set of facts should result in the application of the same substantive law, regardless of the form in which suit is bought'. ${ }^{36}$

Shall we then argue that forum shopping ought to be avoided by the authors of the law in the difficult context of plurality of legal regimes (i.e., in the absence of a coherent legal regime $\left.{ }^{37}\right)$ ?

Harmonized procedural rules consistently applied would both restrain a party from using or continue to shop around different legal remedies and reduce the need for anti-shopping interpretation ${ }^{38}$ and therefore diminish the negative effects of forum shopping. This would result in application of underlying law to identical facts (i.e., same concept of damage and same way of evaluating the amount of damages).

However, even in the presence of harmonized or uniform legal remedies, courts tend to use escape devices (see the Emmot case escape as argued by Peter Wattel $\left.{ }^{39}\right)$ : this behaviour increases the probability that the outcome can vary which in turn again increases forum shopping. Besides, harmonized rules (including legal remedies) are drafted by influent actors ${ }^{40}$ and are not socially optimal. ${ }^{41}$

If we look at legal pluralism in the Hayekian perspective, it can be viewed as a continuously spontaneous order and forum shopping is part of that order and cannot be eliminated, or at least, its elimination does not enhance welfare. In such spontaneous order, as described by Friedrich Hayek, 'the judge will constantly have to decide which [expectation] is to be treated as legitimate and in doing so will provide the cases for new expectations', and 'the development of rules [of just conduct] will ... involve a continuous interaction between the rules of law and expectations'. ${ }^{42}$

However, in the Community law order, the concept of rights and fair procedure belong to the basic tradition of Member States legal systems and have to be reconstructed in democratic procedures. ${ }^{43}$ Legal certainty is in this context a major right that should not be abandoned or given second place by the ECJ. The negative effects to the system of rights resulting from the forum shopping practices and consequent increase of settlement costs (including an increase of the work load of the national courts and ECJ) should not be undervalued, either. An attempt to reduce forum shopping in EC legal remedies should therefore be seriously followed by the EC law actors, although, as previously argued, its elimination is not feasible.

\section{Notes}

33 If all parties could control the information on the strategic choice no adverse selection or moral hazard problems would occur: Kimberly A. More \& Francesco Parisi, 'Rethinking Forum Shopping in Cyberspace', < www.law.gmu.edu/assets/files/publications/working-papers/02-01 >; Francesco Parisi \& Erin A. O'Hara, 'Conflicts of Law', The New Palgrave Dictionary of Economics and the Law, 3rd edn (1999).

34 See on these concepts, Ghei \& Parisi, n. 32 above, 4.

35 Michelle J. White, 'Asbestos Litigation: Procedural Innovations and Forum Shopping', Journal of Legal Studies, 35 (2006): 365 et seq. On the tendency of welfare state to promote overbreeding and its tragic consequences, Fernando Araújo, A Tragédia dos Baldios e dos Anti-Baldios, O Problema Económico do Nivel Óptimo de Apropriação (Coimbra: Almedina, 2008), especially Ch. 2, and the literature therein.

36 Ghei \& Parisi, see n. 32 above.

37 On this issue of fragmented and non-hierarchically differentiated normative systems and search for a uniform concept of law, Klaus Günther, n. 3 above, 541 et seq.

38 See a similar reasoning for cross-border insolvency, Look Chan Ho, 'Anti-suit Injunctions in Cross-Border Insolvency: A Restatement', SSRN: < http://ssm.com/ abstract $=406240>$.

39 Peter J. Wattel, see n. 23 above, 128-132.

40 Klaus Günther, see n. 3 above, 539-547.

41 Ghei and Parisi, see n. 32 above, 11.

42 Friedrich Hayek, Law Legislation and Liberty, A New Statement of the Liberal Principles of Justice and Political Economy, vol. 1 (Rules and Order) (London, Melbourne and Henley: Routledge and Kegan Paul, 1973), 102.

43 Klaus Günther, see n. 3 above, 557 et seq. Jürgen Habermas, 'Zur Legitimation durch Menschenrechte', Die postnationationale Konstellation, Politische Essays (Suhrkamp: Frankfurt-am-Main, 1998), 170 et seq.; 'Ist die Herausbildung einer europaïschen Identität nötig, und ist sie möglich?', Der gespaltene Westen (Suhrkamp: Frankfurt-am-Main, 2004), 79-82. 